\title{
IBM KERUPUK KUNTI
}

\author{
Waluya Jati, Setu Setyawan, Lutfirrahman ${ }^{1}$ \\ Program Studi Manajemen, Universitas Muhammadiyah Malang ${ }^{1}$
}

\begin{abstract}
Abstrak
Pengabdian masyarakat ini dilakukan di Dusun Sukosari Desa Pandansari Poncokusumo Kabupaten Malang. Dusun ini memiliki sumber daya alam yang banyak namun akibat bencana gunung Bromo tidak lagi menghasilkan sebagaimana biasanya. Perkebunan hanya mengandalkan air hujan sehingga banyak waktu yang terbuang dari para petani atau masyarakat pada umumnya. Berdasar identifikasi masalahnya ditemukan bahwa mitra memiliki pengetahuan yang rendag tentang pengelolaan sumber daya alam. Disamping itu motivasi dan pengetahuan tentang wirausaha juga rendah. Akibatnya terjadi penurunan nilai ekonomi masyarakat. Solusi yang ditawarkan adalah penyuluhan, sosialisasi dan diskusi dengan mitra. Hasilnya adalah mitra dapat memahami pengelolaan sumber daya sesuai dengan potensi dan skill masyarakat, serta mitra dapat menganalisis kelayakan usaha yang akan dikembangkan menjadi usaha bersama.
\end{abstract}

Kata kunci: kerupuk kunti, standarisasi produk, pengemasan.

\section{PENDAHULUAN}

Analisis Situasi

Desa Srigading Kecamatan Lawang memiliki Luas Wilayah sebesar 1111,63 Ha, dengan kondisi tanah yang subur. Terdapat 3 dusun yang berada diatas bukit yaitu dusun Mendek, dusun Gading, dan dusun Jeruk dengan udara yang sejuk, sedangkan dusun krajan berada dibawah bukit. Desa Srigading memiliki jumlah penduduk sebanyak 5.372 jiwa yang terdiri dari 2.639 orang laki-laki dan 2.733 orang perempuan. Keadaan sosial ekonomi Desa Srigading dapat dikatakan cukup baik. Hal ini dikarenakan sebagian besar penduduk desa bekerja di sektor pertanian dan pengrajin kayu. Ada juga masyarakat yang wirausaha sebagai penjual kelontongan dan budidaya jamur. Perekonomian dan sumber mata pencarian warga Masyarakat Desa Srigading secara umum sangat bervariasi, mengingat lokasi desa srigading yang berdekatan dengan Pasar Baru Lawang, dan semakin sedikitnya lahan pertanian yang ada. Berikut data jumlah penduduk beserta mata pencahariannya, antara lain :

\begin{tabular}{lll}
\multicolumn{2}{c}{ Tabel 1. Mata Pencaharian } & Warga Desa Srigading \\
\hline No & Mata Pencaharian & Jumlah Orang \\
\hline 1 & Petani/Penggarap & 2.285 \\
2 & Penjahit & 10 \\
3 & Pegawai Negeri Sipil & 4 \\
4 & TNI/POLRI & 3 \\
5 & Pengrajin Kayu & 85 \\
6 & Sopir & 25 \\
7 & Karyawan Swasta & 631 \\
8 & Tukang Batu & 94 \\
9 & Buruh Tani & 1613 \\
10 & Guru Swasta & 2 \\
\hline
\end{tabular}

Sumber: data diolah

\footnotetext{
1 lutfisukses@yahoo.co.id
} 
Kerupuk kunti yang memiliki rasa khas singkong ini kini mulai banyak dikenal masyarakat di luar Desa Srigading dikarenakan selain rasanya yang khas dibandingkan kerupuk yang lain kerupuk kunti juga dikenal aman karena menggunakan bahan-bahan alami dalam proses produksinya dengan bumbu-bumbu sederhana yang dapat ditemukan setiap hari di dapur. Akan tetapi, sampai saat ini aparat desa serta masyarakat Desa Srigading sendiri belum menyadari bahwa kerupuk kunti memiliki potensi yang sangat besar untuk menjadi produk unggulan Desa Srigading dan dapat memberikan kontibusi besar pada bertambahnya sumber pendapatan masyarakat desa, ekonomi pedesaan serta sumber pendapatan Desa Srigading.

\section{Identifikasi Masalah}

Berdasarkan gambaran analisis situasi diatas, maka dapat diambil beberapa permasalahan sebagai berikut:

a. Minimnya sumber pendapatan asli Desa dari hasil pemberdayaan masyarakat desa

b. Belum adanya kesadaran akan manfaat dan inisiatif aparatur desa untuk mengembangkan home industry di desa srigading

c. Keterampilan manajerial Aparatur Desa belum memiliki jiwa wirausaha sehingga produk kerupuk kunti hanya menjadi bahan konsumsi harian masyarakat Desa dan tidak terfikir untuk menjadikannya sebagai produk unggulan Desa yang dapat di jual keluar desa.

d. Belum terdapatnya standarisasi peracikan bahan produksi kerupuk kunti yang menyebabkan rasa kerupuk kunti hasil produksi satu warga dengan warga lain berbeda

e. Kurangnya inovasi dan kreatifitas dalam pengemasan produk kerupuk kunti

f. Tidak terdapatnya informasi produk dalam kemasan sehingga sulit menarik kepercayaan konsumen terhadap produk kerupuk kunti

g. Teknologi yang digunakan dalam proses produksi masih tradisional, sehingga belum dapat dijaminya higienitas produk dalam proses produksinya

Kurangnya pengetahuan tentang pemasaran dan manajemen pemasaran produk, serta akses pasar

\section{Materi Dan Metode Pelaksanaan}

Sebagai upaya menangani permasalahan-permasalahan yang ada, maka solusi yang ditawarkan adalah sebagai berikut:

a) Memberikan sosialisasi kepada masyarakat melalui kegiatan pertemuan warga yang terdiri dari ibu-ibu anggota kelompok PKK dan Perangkat Desa tentang potensi produk asli Desa Srigading Kerupuk Kunti menjadi Produk Olahahan Unggulan Desa.

b) Membentuk kelompok produksi kerupuk kunti khas Desa Srigading

c) Memberikan penyuluhan dan pelatihan tentang pentingnya standarisasi resep dan proses produksi kerupuk kunti untuk menuju produk olahan unggulan Kerupuk Kunti Khas Desa Srigading yang dapat di pasarkan secara luas.

d) Pelatihan kepada warga calon anggota kelompok terkait standarisasi resep produksi kerupuk kunti Khas Desa Srigading dan standarisasi proses pembuatannya, sampai pada pengemasan dan pemasaran produk.

e) Pendampingan secara berkala dalam mengembangkan kelompok produksi kerupuk kunti khas Desa Srigading.

Berdasarkan kerangka diatas, maka langkah-langkah realisasi pemecahan masalah yang di hadapi Desa Srigading adalah dengan kegiatan-kegiatan yang direncanakan dengan berdasarkan pada rangkaian kegiatan sebagai berikut:

Tabel 3. Langkah-langkah Realisasi Pemecahan Masalah

\begin{tabular}{ll}
\hline Kegiatan & Luaran \\
\hline $\begin{array}{l}\text { Observasi dan } \\
\text { Kunjung Lapang }\end{array}$ & $\begin{array}{l}\text { Data resep/bahan Kerupuk Kunti, } \\
\text { deskripsi tahapan proses pembuatan } \\
\text { dan sampel produk. }\end{array}$ \\
$\begin{array}{l}\text { Sosialisasi } \\
\text { rencana program }\end{array}$ & $\begin{array}{l}\text { Kelompok produksi Kerupuk Kunti } \\
\text { dan pendampingan. }\end{array}$ \\
$\begin{array}{l}\text { Pelatihan Proses } \\
\text { Produksi }\end{array}$ & $\begin{array}{l}\text { Standart resep dan proses produksi } \\
\text { Kerupuk Kunti Khas Desa }\end{array}$ \\
\hline
\end{tabular}




\begin{tabular}{|c|c|}
\hline Kegiatan & Luaran \\
\hline & Srigading. \\
\hline $\begin{array}{l}\text { Pendampingan } \\
\text { Pengemasan } \\
\text { Kerupuk Kunti }\end{array}$ & $\begin{array}{l}\text { Kemasan Kerupuk Kunti yang lebih } \\
\text { menarik dan inovatif. }\end{array}$ \\
\hline $\begin{array}{l}\text { Pendampingan } \\
\text { Pemasaran } \\
\text { Kerupuk Kunti }\end{array}$ & $\begin{array}{l}\text { Terpasarkan di toko oleh-oleh khas } \\
\text { malang di wilayah malang raya. }\end{array}$ \\
\hline $\begin{array}{l}\text { Monitoring dan } \\
\text { Evaluasi }\end{array}$ & Laporan kemajuan \\
\hline Pelaporan & $\begin{array}{l}\text { Laporan publikasi kegiatan program } \\
\text { pengabdian. }\end{array}$ \\
\hline
\end{tabular}

\section{HASIL DAN PEMBAHASAN}

Kegiatan ini dilaksanakan di dusun krajan, hal ini dilakukan karna pertama, kegiatan pengabdian ini adalah kegiatan inisiasi untuk membuka kesadaran warga desa srigading akan potensi kerupuk kunti, diharapkan jika program ini berhasil di dusun krajan, maka dusun-dusun lain akan mengikuti jejak dusun krajan. Kedua, dusun krajan merupakan dusun dengan jumlah warga paling banyak dan dekat dengan akses pemerintahan desa.

Inisiasi yang dilakukan Tim pengabdian adalah dengan membuat kelompok produksi kerupuk kunti khas desa srigading, kelompok yang coba dibuat tim pengabdian kali ini adalah sebuah kelompok kecil yang didalamnya terdiri dari 3 orang anggota. Orang-orang tersebut adalah orang-orang yang dipilih khusus karna kemampuan dan intensitasnya dalam membuat kerupuk kunti. Nama-nama anggota kelompok produksi kerupuk kunti khas desa srigading yang di bentuk tim pengabdian adalah 1) Ibu Musliha; 2)Ibu Saniti; dan 3) Ibu Wati hadori yang kebetulan beliau adalah ibu kepala desa srigading. Ketiga anggota tim inilah yang nantinya akan memproduksi kerupuk kunti khas desa srigading sampai dengan pemasarannya. Berdasarkan gambaran di atas, dapat dicermati bahwa kelompok usaha kerupuk kunti khas desa srigading ini nantinya sebenarnya cukup potensial untuk di kembangkan lebih lanjut karena seluruh warganya mampu membuat kerupuk kunti, sehingga dapat menghasilkan kapasitas produksi yang cukup besar walaupun kemampuan SDM yang terbatas, namun tetap dapat dikembangkan dengan penyuluhan, pelatihan dan pendampingan

Berikut penduan pembuatan tepung singkong tradisional dengan mudah.

1. Kupas singkong dari kulitnya.

2. Bersihkan singkong menggunakan air bersih dan pastikan lendir yang berada diantara kulit dan daging umbi juga bersih. Pembersihan bisa dilakukan dengan cara menyikat permukaan umbi singkong.

3. Potong-potong singkong setipis mungkin, ini dimaksudkan untuk mempercepat proses pengeringan nantinya.

4. Rendam singkong dalam air bersih selama minimal 2 hari 2 malam, proses ini akan menghasilkan endapan tepung tapioka. Pisahkan tepung dan keringkan untuk keperluan berikutnya.

5. Selama proses perendaman, air harus diganti maksimal 24 jam sekali atau lebih bagus 12 jam sekali, jika tidak hasil tepung akan menyisakan bau seperti bau singkong yang busuk terendam.

6. Angkat singkong dari rendaman dan jemur hingga benar-benar kering dengan kadar air kurang lebih $10 \%$, cirinya singkong mulai lapuk/rapuh.

7. Saatnya proses penggilingan (orang desa biasa menyebut dengan istilah "selep"), jika tidak ada alat giling kita juga bisa menumbuknya menggunakan lumpang hanya saja prosesnya lebih lama.

8. Ayak singkong hasil tumbukan dengan ayakan tepung, alat ini banyak dijual di toko tempat penjualan perkakas rumah tangga. Sisa ayakan dapat ditumbuk kembali sampai benar-benar halus.

9. Satukan tepung hasil ayakan dengan tepung tapioka yang diperoleh dari hasil perendaman dan jemur kembali sampai benar-benar kering. 
10. Tepung singkong sudah siap digunakan, jika tidak digunakan secara langsung simpan pada wadah/plastik yang tertutup rapat
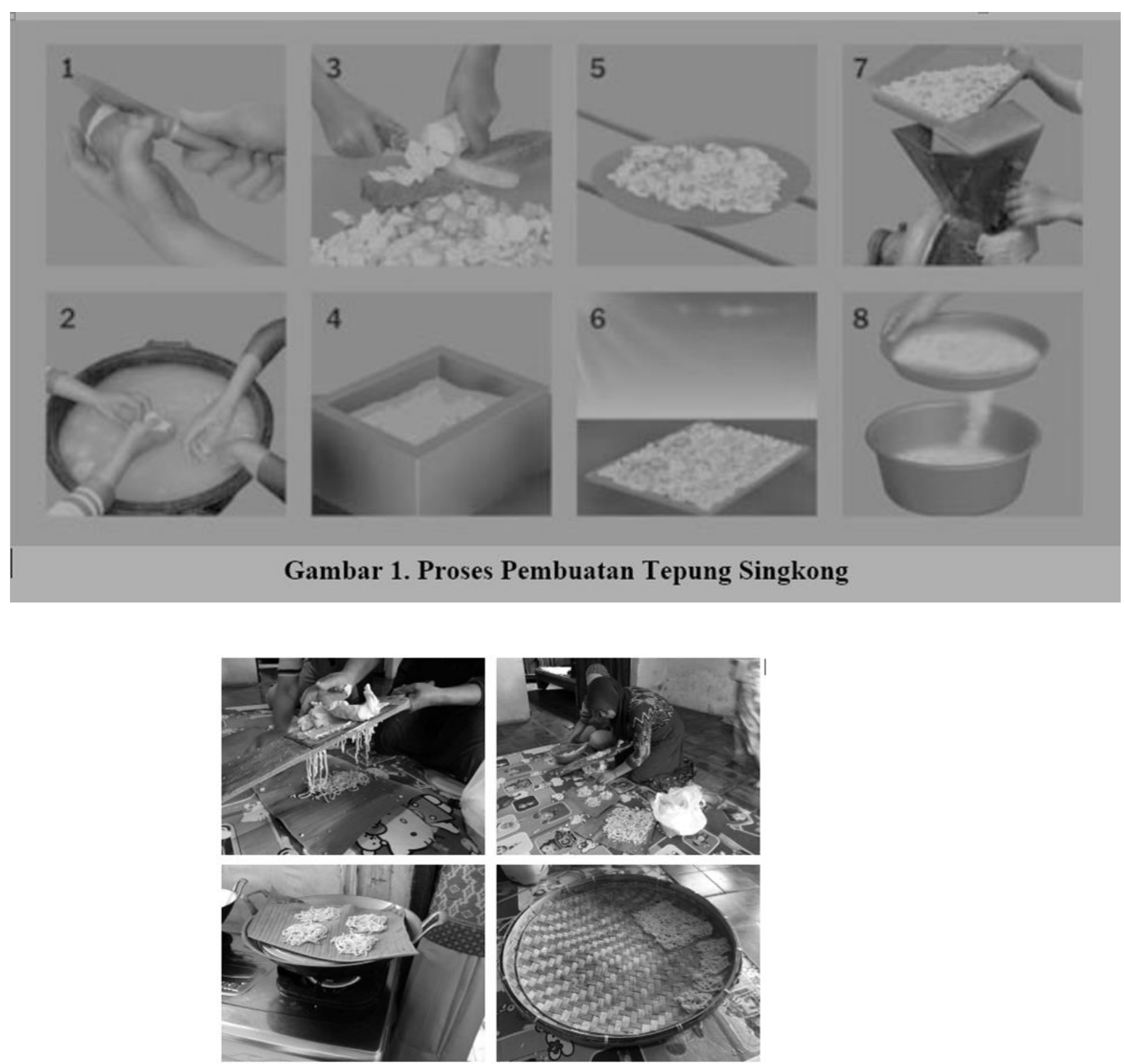

Gambar 2. Proses Pembuatan Kerupuk Kunti Mentah (cara tradisional)

\section{KESIMPULAN}

Berdasarkan hasil pengabdian, dapat diperoleh kesimpulan sebagai berikut:

Berkaitan dengan proses produksi atau pengolahan kerupuk kunti, standarisasi resep dan proses pengolahan dalam pembuatan kerupuk kunti ini ditujukan untuk konsistensi kualitas hasil dan rasa produk kerupuk kunti yang di produksi oleh seluruh anggota produksi kerupuk kunti khas Desa Srigading. Karna itu, dibuatlah standar resep dan pengolahan kerupuk kunti yang di sepakati oleh seluruh anggota dan perangkat Desa.

Seluruh anggota memiliki keinginan yang sama dalam hal menimbulkan minat serta kepercayaan konsumen terhadap produk kerupuk kunti khas Desa Srigading, pengemasan produk yang menarik dan pemberian informasi yang cukup terkait kerupuk kunti menjadi salah satu cara dalam membangun minat 
dan kepercayaan konsumen pada produk kerupuk kunti khas Desa Srigading. Observasi dan penentuan pengemasan produk kerupuk kunti khas Desa Srigading yang inovatif dan modern sesuai dengan kondisi pasar menjadi bagian dari pengemasan dan proses penyediaan informasi produk bagi konsumen, pengemasan yang sesuai dan informasi yang lengkap yang tercantum di dalamnya akan membantu dalam menimbulkan minta dan memberikan kepercayaan pada konsumen atas produk yang akan mereka konsumsi.

Permasalahan pada aspek pemasaran yaitu dimulai dari kemampuan para anggota serta perangkat Desa dalam membaca peluang pasar dan kemampuan berinovasi, sehingga dalam hal pengemasan produk kerupuk kunti yang dihasilkan, anggota hanya mengemasnya dengan cara yang sederhana (atau bisa di sebut "tidak dikemas"). Inovasi dalam pengemasan akan membantu mendorong produk kerupuk kunti untuk masuk kedalam berbagai segmentasi pasar di segala lapisan. Selain itu, kerupuk kunti belum banyak memenuhi ketentuan-ketentuan standar untuk dapat dipasarkan secara meluas di pasar modern seperti di toko oleh-oleh karena masih memiliki kekurangan seperti belum tercantumnya tanggal kadaluwarsa, PIRT, Konsitensi bentuk dan rasa produk, dan beberapa ketentuan lainnya

\section{Saran}

Adapun saran dari hasil pengabdian ini adalah sebagai berikut:

1. Anggota kelompok produksi kerupuk kunti khas Desa Srigading diharapkan selalu mentaati standar resep dan pengolahan kerupuk kunti yang di buat agar hasil dan rasa yang dihasilkan dalam setiap proses produksi kerupuk kunti selalu konsisten dan terjaga kualitasnya. Pengembangan resep dan pengolahan produk kerupuk kunti harus selalu dilakukan seiring dengan perkembangan permintaan pasar kerupuk kunti, hingga eksistensi kerupuk kunti khas Desa Srigading dapat terjaga.

2. Penyediaan informasi yang lebih lengkap bagi produk kerupuk kunti khas Desa Srigading seperti Informasi Tanggal Kadaluwarsa, P-IRT, Informasi BPOM yang saat ini belum di miliki oleh kerupuk kunti khas Desa Srigading harus terus di upayakan oleh anggota produksi kerupuk kunti khas Desa Srigading, sebagai komitmen anggota untuk menjaga minat dan kepercayaan konsumen terhadap produk kerupuk kunti.

3. Kelompok produksi kerupuk kunti khas Desa Srigading beserta Perangkat Desa diharapkan dapat terus melakukan inovasi terkait dengan rasa, bentuk, jenis dan pengemasana kerupuk kunti untuk menarik minat konsumen terhadap Kerupuk Kunti Khas Desa Srigading.

\section{UCAPAN TERIMAKASIH}

Dengan terselesaikannya kegiatan pengabdian ini, maka kami sampaikan terimakasih yang sebesar-besarnya kepada Rektor Universitas Muhammadiyah Malang, Dekan Fakultas Ekonomi \& Bisnis, beserta jajarannya yang telah memberikan dana kegiatan ini sehingga dapat selesai dengan lancar dan tak kurang satu apapun. serta Pusat pengembangan Ekonomi Bisnis dan Kewirausahaan (PPEBK) selaku unit pelaksana teknis di bawah Fakultas Ekonomi dan Bisnis yang membantu pelaksanaan pengabdian ini melalui sistem Pengabdian Blockgrant. Terimakasih juga untuk Warga serta Pemerintahan Desa Srigading yang telah memberikan banyak isnpirasi serta kesempatan tim untuk bekerjasama melakukan pengabdian masyarakat ini.

\section{REFERENSI}

Christine Suharto Cenadi. 2000. Peranan Desain Kemasan dalam Dunia Pemasaran. NIRMANA Vol. 2, No. 1. Surabaya.

Kotler, Philip. Marketing 1. Penerbit Erlangga, Jakarta, 1987.

Wirya, Iwan. Kemasan yang Menjual. PT. Gramedia Pustaka Utama, Jakarta, 1999. 2012. Petunjuk Teknis Cara Produksi Pangan Olahan yang Baik Untuk Pangan Gorengan.

Direktorat Jenderal Industri Kecil dan Menengah, Kementerian Perindustrian, Jakarta. 
2015. Pedoman Cara Menggoreng Pangan yang Baik untuk Usaha Mikro, Kecil dan Menengah (UMKM). Direktorat Standarisasi Produk Pangan, Deputi Bidang Pengawasan Keamanan Pangan dan Bahan Berbahaya, Badan Pengawasan Obat dan Makanan Republik Indonesia. Jakarta. 